\title{
PROTEROZOIC AND EARLY PALAEOZOIC MICROFOSSILS IN THE KARIKKOSELKÄ IMPACT CRATER, CENTRAL FINLAND
}

\begin{abstract}
ANNELI UUTELA
UUTELA, ANNELI 2001. Proterozoic and early Palaeozoic microfossils in the Karikkoselkä impact crater, central Finland. Bulletin of the Geological Society of Finland 73, Parts 1-2, 75-85.

The Karikkoselkä impact crater is located at Petäjävesi (Lat. 62 $13.3^{\prime}$ N, Long. $25^{\circ} 14.7^{\prime} \mathrm{E}$ ), in central Finland. The crater is filled with impact-generated breccias and redeposited sedimentary rock yielding microfossils. The assemblage consists of Proterozoic, Cambrian and Ordovician acritarchs, cyanobacteria and green algae thoroughly mixed in the deposit. The late Ordovician acritarch Diexallophasis striatum indicates the maximum age of the impact event in the Keila Regional Stage, middle Caradocian in British Series, 458-449 Ma or later. A till sample overlying the sediments that infill the crater yields only Quaternary pollen and spores, indicating that the impact event occurred prior to the Fennoscandian Ice Age. The most likely palaeomagnetic age of 260-230 Ma (late Permian to early Triassic) is neither excluded nor supported by the microfossil results. However, other palaeomagnetic ages are excluded leaving this the most likely age. This article presents new evidence of Proterozoic and early Palaeozoic deposits that covered central Finland.
\end{abstract}

Key words: impact craters, sedimentary rocks, microfossils, acritarchs, cyanobacteria, Chlorophyta, Paleozoic, Proterozoic, Karikkoselkä, Finland

Anneli Uutela: Finnish Museum of Natural History, Geological Museum, P.O. Box 4, FIN-00014 University of Helsinki, Finland 


\section{INTRODUCTION}

Thus far, nine meteorite impact structures have been recorded in Finland: six of them are filled with PreQuaternary sedimentary rocks containing fossils, i.e. Lappajärvi (age $77 \mathrm{Ma}$ ) (Svensson 1968, Lehtinen 1976, Jessberg \& Reimold 1980, Uutela 1990, 1998) and Söderfjärden (age 530-510 Ma) (Laurén et al. 1978, Tynni 1978, 1982a, Lehtovaara 1984, 1985, Hagenfeldt 1989a, b, Abels et al. 2000) in western Finland, Iso-Naakkima (age 1000-650 Ma) (Elo et al. 1993) in central Finland, Lumparn in Åland (age 600-443Ma) (Tynni 1982b, Svensson 1993, Abels et al. 2000) in south-western Finland, Saarijärvi in northern Finland (unknown age between 2450-500 Ma) (Tynni \& Uutela 1985, Öhman et al. 2000), and the Karikkoselkä impact crater - the subject of this paper.

The Karikkoselkä impact crater is located in the municipality of Petäjävesi $\left(62^{\circ} 13.3^{\prime} \mathrm{N}, 25^{\circ} 14.7^{\prime}\right.$ E, Fig. 1), in central Finland, ca. $25 \mathrm{~km}$ west of the town of Jyväskylä and $230 \mathrm{~km}$ north of Helsinki. During the first field trip in summer 1995, Dr Martti Lehtinen, and later in autumn 1995 together with Dr Lauri Pesonen, found shatter cones in situ on shoreline outcrops, the first evidence of the impact origin of the Karikkoselkä circular structure (Lehtinen et al. 1996, Pesonen et al. 1997, 1998). Acoustic surveys were made during 1996 and 1997 to determine the topography of the lake bottom and to estimate the thickness of sediments. In winter 1996, Geological Survey of Finland carried out the first deep drilling, but the Proterozoic rock basement was not reached, however, in 1998, two drill cores were drilled successfully (Fig. 1). Moreover, estimations of the impact origin of the Karikkoselkä structure were supported by extensive fracturing of target rock, shock metamorphic features in breccias, and shatter cone like features in outcrops of porphyritic granite (Pesonen et al. 1999, Arkonsuo 2000).

This well-preserved, simple impact structure has a diameter of $2.1-2.4 \mathrm{~km}$. The lake is deep $(26.5 \mathrm{~m})$ with steep shores, which is exceptional in central Finland where typical Quaternary lakes are shallow, generally less than $10 \mathrm{~m}$ deep. The diameter of the lake itself is $1.2 \mathrm{~km}$ and it is situ- ated at 110.9 metres above sea level.

The gravity and electromagnetic models are mutually consistent and suggest a depth of ca. 120 $\mathrm{m}$ for the bottom of the sediment and/or breccia layer, thus implying an anomalously shallow structure (depth/diameter $<0.1)$. According to Pesonen et al. (1999), palaeomagnetic data suggest an age of 260-230 Ma (Late Permian to Early Triassic) for the impact, but older age interpretations are also possible, i.e. 560-530 Ma (late Neoproterozoic to early Cambrian) and less likely, 1760-1650 Ma (late Palaeoproterozoic) (Fig. 2).

In addition to palaeomagnetic dating, fossils are valuable tools for age determination. Because the Karikkoselkä impact crater is filled with sedimentary rocks (mudstone and sandstone), fossils can help in estimating the age of the impact event. Fossils can also provide evidence for pre-impact deposits and serve as an important reservoir of Phanerozoic geological history, which has been largely eroded by continental ice elsewhere in the country.

\section{MATERIAL AND METHODS}

The Karikkoselkä crater is filled with chaotically occurring, redeposited sedimentary rocks and breccias with shock-metamorphic features. The

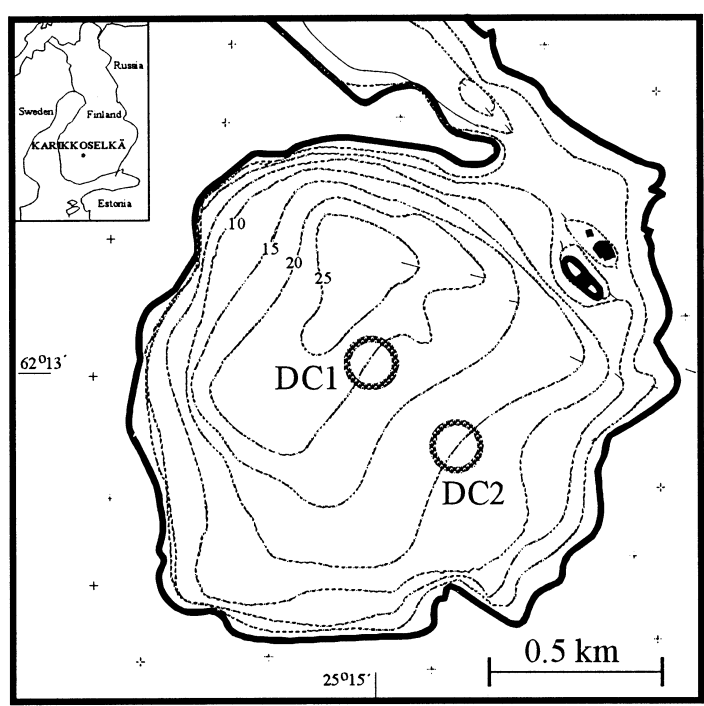

Fig. 1. Location of Lake Karikkoselkä and sites of drill cores DC1 and DC2. Water depth contours are in metres. 


\begin{tabular}{|c|c|c|c|}
\hline \multicolumn{2}{|c|}{\begin{tabular}{l|l} 
Eon & Era \\
\end{tabular}} & Period & $\mathrm{Ma}$ \\
\hline \multirow{11}{*}{ 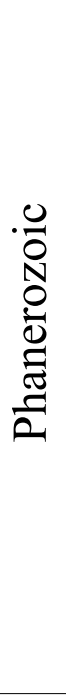 } & \multirow{2}{*}{$\begin{array}{l}\cdot 0 \\
0 \\
0 \\
0 \\
0 \\
0\end{array}$} & Quaternary & 1.8 \\
\hline & & Tertiary & 65 \\
\hline & \multirow{3}{*}{ 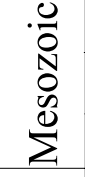 } & Creatceous & 145 \\
\hline & & Jurassic & 213 \\
\hline & & Triassic & 284 \\
\hline & \multirow{6}{*}{ 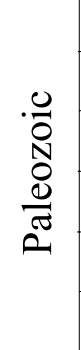 } & Permian & 286 \\
\hline & & Carboniferous & 360 \\
\hline & & Devonian & 410 \\
\hline & & Silurian & 440 \\
\hline & & Ordovician & 505 \\
\hline & & Cambrian & 544 \\
\hline \multirow{5}{*}{ 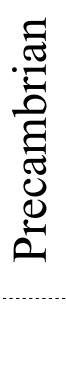 } & \multirow{4}{*}{$\begin{array}{l}\text { శే } \\
\text { 더 }\end{array}$} & Neoproterozoic & 900 \\
\hline & & Mesoproterozoic & 1600 \\
\hline & & Palaeoproterozoic & 2500 \\
\hline & & Archaean & 3800 \\
\hline & & & 4500 \\
\hline
\end{tabular}

Fig. 2. The geologic time scale (Hansen 1991, Topinka 2001).

sedimentary rocks of greenish, greyish and brownish mudstone and siltstone yield organic-walled microfossils, i.e. cyanobacteria, green algae (Phrasinophyceae) and acritarchs (Group Acritarcha). The term acritarch in used later in the text to refer to these three collectively.

Arkonsuo (2000) has given a detailed description of the lithology of drill cores, and Figure 3 shows a simplified description of them.

In drill core DC $1\left(62^{\circ} 13.2^{\prime} \mathrm{N}, 25^{\circ} 14.9^{\prime} \mathrm{E}\right.$, dip $65.65^{\circ}$ south) sedimentary rocks occur from 33.90 to $161.20 \mathrm{~m}$ (a total of $127.30 \mathrm{~m}$ ), overlying Proterozoic porphyritic granite target. The lowermost sample (a depth of $168.00 \mathrm{~m}$ ) consists of mudstone clasts among breccia. The major part of the deposit is polymictic allochthonous breccia with angular, subangular or rounded grey mudstone clasts which is intercalated with mudstone and siltstone layers at a depth of 144.20-133.65 m and 123.70$99.30 \mathrm{~m}$. Porphyrite granite is intercalated with polymictic allochthonous breccia at a depth of 45.70-45.00 m, 44.65-43.50 m and 40.80-39.00 $\mathrm{m}$. Variably red and grey siltstone underlies Quaternary till at a depth of 39.00-33.90 m.

Drill core DC2 is located $260 \mathrm{~m}$ southeast of DC1. In DC2 (dip $88.10^{\circ}$ south) sedimentary rocks occur from 26.10 to $131.00 \mathrm{~m}$ (totalling 104.80 $\mathrm{m})$, overlying porphyrite granite target with breccia dikes. Pebbly grey sandstone at a depth of $131.00-123.20 \mathrm{~m}$ is intercalated with polymictic allochthonous breccia with angular, subangular or rounded grey mudstone clasts at a depth of 127.20-123.45 m. At a depth of 123.20-92.45 m, polymictic allochthonous breccia with clay clasts underlies reddish siltstone $(92.45-81.50 \mathrm{~m})$, brown mudstone (81.50-66.65 $\mathrm{m}$ ) and brown mudstone with silty or sandy layers $(66.65-26.10 \mathrm{~m})$, the overlying $35 \mathrm{~m}$ part of the deposit being subvertically laminated. The uppermost sample at a depth of 13.80 m consists of Quaternary till.

For microfossil analysis, 51 samples from DC1 and 27 samples from $\mathrm{DC} 2$ were treated with $\mathrm{HCl}$ and $\mathrm{HF}$ before filtering the residue through an 8 $\mu \mathrm{m}$ nylon sieve (Vidal 1988), about $50 \mathrm{~g}$ of material was used for each sample. The sample interval is irregular, because only greenish or greyish mudstone samples and pebbly sandstone with greenish and greyish pebbles of mudstone were prepared based on previous studies of barren brownish or reddish material. Occurrence and distribution of the microfossils found in the drill cores are shown in Tables 1 and 2. All the microfossils were counted.

\section{RESULTS}

Generally, the acritarchs are well preserved, and, although some specimens are mechanically broken, no signs of thermal heating have been observed. In the Karikkoselkä impact crater, the acritarch assemblage is a mixture of Proterozoic and early Palaeozoic, i.e. Cambrian and Ordovician species. Taxonomic diversity is low, a total of 19 


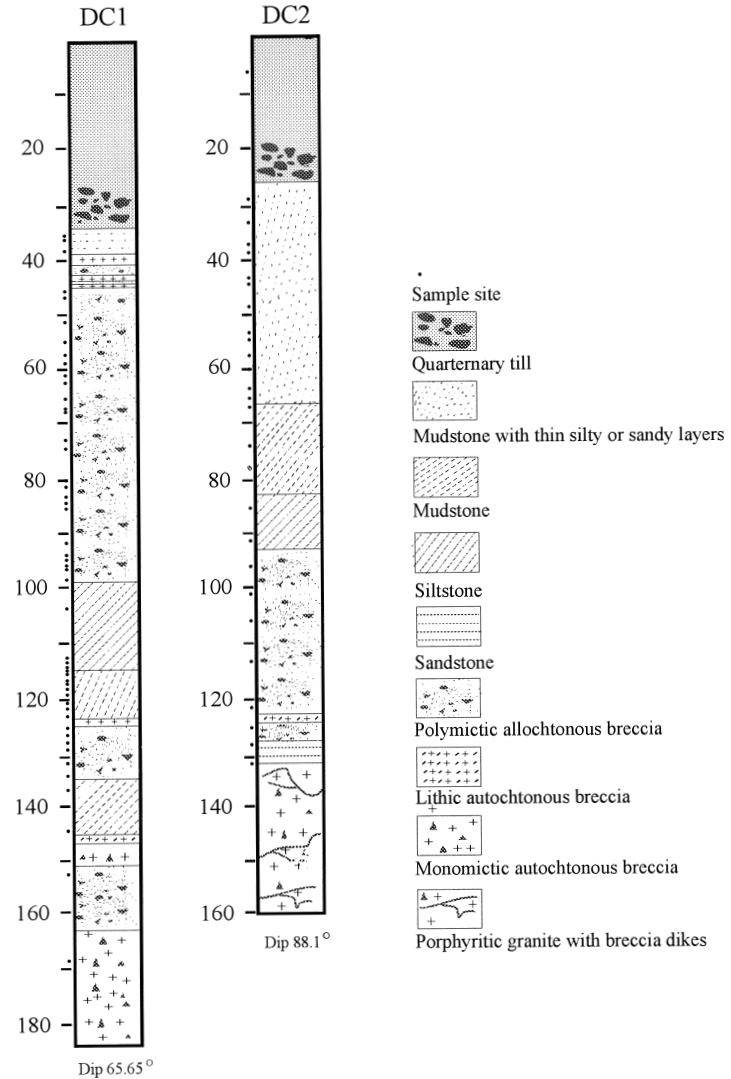

Fig. 3. Lithological description of drill cores DC1 and DC2 (modified after Arkonsuo 2000), and sample sites.

species was recorded from DC1: five Proterozoic, three Proterozoic to Cambrian, five Cambrian and six Ordovician species. Leiosphaeridia species are presented separately because of their minor stratigraphic value (Table 1). Of the six species recorded in DC2, two are Proterozoic, two Cambrian and two Ordovician (Table 2). The nomenclature is partly modified after Sarjeant and Stancliffe (1994).

Nearly $80 \%$ of all the specimens belong to the genus Leiosphaeridia Eisenack, 1938. Despite being thin walled they are well preserved. Their colour is light yellow, and neither signs of heating nor mechanical destruction were observed. The diameters of the cells vary from less than $10 \mu \mathrm{m}$ to more than $200 \mu \mathrm{m}$, and more than $55 \%$ of the specimens are smaller than $40 \mu \mathrm{m}$ in size. The dating value of Leiosphaeridia species is generally small, because of their long living range, i.e. from Protero- zoic to Tertiary (Moczydlowska 1991).

The number of acritarchs at different depths in the drill cores is shown in Tables 1 and 2. Among the acritarch assemblage, none of the species have ranges restricted to the Mesoproterozoic Era.

Only a few species are restricted to the Neoproterozoic Era. Thick-walled cells or cell fragments of Chuaria circularis Walcott, 1899 emended Vidal \& Ford, 1985 (4 specimens and one fragment, Plate I, Fig. A2) were recorded only in DC1 from a depth of $66.50 \mathrm{~m}$ to $80.55 \mathrm{~m}$. The cell diameter is more than $300 \mu \mathrm{m}$, and its large size differentiates the species from other smooth and thick-walled sphaeromorphic species, e.g. Leiosphaeridia-species (Hofmann \& Jackson 1994). Chuaria circularis is recorded from numerous occurrences worldwide (Samuelsson \& Strauss 1999), and its stratigraphic range is restricted to early Neoproterozoic (Vidal et al. 1993). In Finland this species has been previously recorded in Vendian, i.e. Neoproterozoic deposits at Hailuoto (Tynni \& Donner 1980).

The irregularly reticular surface of the thickwalled cell of Trachysphaeridium laminaritum Timofeev, 1966 (4 specimens in DC1) is the characterizing feature of the species. In the present material their size is ca. $30 \mu \mathrm{m}$, which is smaller than in the original diagnosis by Timofeev (1966), Samuelsson (1997), however, has also recorded smaller specimens. According to Samuelsson (1997), the stratigraphic range of T. laminaritum is restricted to the Neoproterozoic (Upper Riphean to Vendian), according to Timofeev (1966) its living range extends to slightly later, to early Cambrian. In Finland the species has previously been recorded in the Riphean, i.e. Mesoproterozoic Muhos formation. The specimens recorded there were larger, 100-129 $\mu \mathrm{m}$ in size (Tynni \& Uutela 1984).

Three taxa have a stratigraphical range from Mesoproterozoic to Cambrian or even younger strata. Rather loose cell clusters of Synsphaeridium spp. (121 specimens, > 40\%, Plate I, Fig. A1) are common only in DC1 at a depth of $46.80 \mathrm{~m}$, at other levels they are rare. The size of a single cell is ca. $5 \mu \mathrm{m}$. Genus Synsphaeridium Eisenack, 1965 appeared in the Mesoproterozoic and disappeared in the Carboniferous Period (Hagenfeldt 
1989a). In Finland, Synsphaeridium species have been previously recorded at Muhos (Tynni \& Uutela 1984) and at Hailuoto (Tynni \& Donner 1980), but also in the Neoproterozoic (Vendian) strata of the Saarijärvi impact crater at Taivalkoski (Tynni \& Uutela 1985) as well as in the Cambrian deposits of the Söderfjärden crater (Tynni 1978, 1982a, Hagenfeldt 1989a).

In the genus Symplassosphaeridium Timofeev, 1959 cells are clustered together more tightly forming a more regular spheroid than cells in the genus Synsphaeridium. Often these two genera are combined together into Synsphaeridium (cf. Samuelsson 1997). In DC2 two Symplassosphaeridium specimens have a diameter of ca. $20 \mu \mathrm{m}$, such small specimens have also been found at Muhos (Tynni \& Uutela 1984). The specimens found at Hailuoto are notably larger in size (Tynni \& Donner 1980). Both genera Synsphaeridium and Symplassosphaeridium have a long stratigraphic range, which makes them biostratigraphically less valuable (Hofmann \& Jackson 1994). However, they are more common in pre-Varangerian deposits than in younger strata (Samuelsson 1997).

Small (diameter 10-15 $\mu \mathrm{m}$, height of velum 2$3 \mu \mathrm{m}$ ), slightly granulated cells with equatorial velum specimens of genus Granomarginata Naumova, 1961 are common (56 specimens, 33\%) in DC1 at a depth of $144.70 \mathrm{~m}$, and the genus is also recorded as rare at depths of 46.00 to $80.55 \mathrm{~m}$. Granomarginata specimens in the present material resemble Cambrian Granomarginata squamacea Volkova, 1968, but they are almost twice as large. Rather similar Granomarginata sp. recorded at Muhos were also larger in size (Tynni \& Uutela 1984). Cambrian species of genus Granomarginata are often recorded in the Baltic area (Naumova 1960, Volkova 1968, Moczydlowska 1991), in Russia its range is from Mesoproterozoic to Silurian (Chibrikova 1972, Lopukin 1974).

Assemblage yields also fragments of psilate threads of filamentous cyanobacteria, which are attributed to the genus Siphonophycus Schopf, 1968, emended Knoll, Swett \& Mark, 1991, narrow to Siphonophycus rugosum (Maithy, 1975) Hofmann \& Jackson, 1994 (width 6.5-13 um) and wide to Siphonophycus kestron Schopf, 1968 (width 14-20 $\mu \mathrm{m}$ ), subdivision according to Hofmann and Jackson (1994). S. rugosum is common in both drill cores in the upper part of the deposit, while S. kestron is rare throughout the deposit (Plate I, Fig. A4). The length of fragments is usually less than $50 \mu \mathrm{m}$. In Finland, Siphonophycus threads (width 8-13 $\mu \mathrm{m}$ ) have been recorded at Muhos (Tynni \& Uutela 1984). Siphonophycus threads are common in benthic mat communities (Hofmann \& Jackson 1994).

Two fragments of narrow pseudo-septate threads (width $20 \mathrm{~mm}$, height of septa $5 \mu \mathrm{m}$ ), attributed to genus Oscillatoriopsis Schopf, 1968 were found in DC1 at a depth of $96.40 \mathrm{~m}$ (Plate I, Fig. A3). They resemble Neoproterozoic (Vendian) Oscillatoriopsis constricta Tynni \& Donner, 1980 described at Hailuoto (Tynni \& Donner 1980), although they are still narrower $(12 \mu \mathrm{m})$ and also partly constricted. Samuelsson (1997) has also recorded narrow Oscillatoriopsis specimens in the early Neoproterozoic deposits in the Kola Peninsula, Russia. Oscillatoriopsis magna Tynni \& Donner, 1980 recorded at Hailuoto are markedly wider (80-100 $\mu \mathrm{m}$, Tynni \& Donner 1980). Both genera Siphonophycus and Oscillatoriopsis are well known from Neoproterozoic occurrences worldwide, but they are not stratigraphically significant (Hofmann \& Jackson 1994).

Five acritarch species are attributed to Cambrian. The small granulated Filisphaeridium tornatum (Volkova, 1968) Sarjeant \& Stancliffe, 1994 species is common only in DC1 at a depth of $144.70 \mathrm{~m} \mathrm{(34 \% ),} \mathrm{it} \mathrm{is} \mathrm{rare} \mathrm{elsewhere} \mathrm{in} \mathrm{the} \mathrm{de-}$ posit. In DC2 only one specimen is found at a depth of $106.5 \mathrm{~m}$.

Genus Tasmanites Newton, 1875, emended Schopf, Wilson \& Bentall, 1994 is attributed to green algae (Phrasinophyceae). Pores of thickwalled Tasmanites volkovae Kirjanov, 1974 are characteristically visible (Plate I, Fig. B5), while T. tenellus Volkova, 1968 is thin-walled and the pores are irregularly situated in the cell (Plate I, Fig. B7). In the present material most of the Tasmanites specimens are mechanically broken. A total number of 69 cells or cell fragments of T. volkovae are found in DC1 and two in DC2. DC1 yields twelve T. tenellus specimens. One fragment of Ski- 


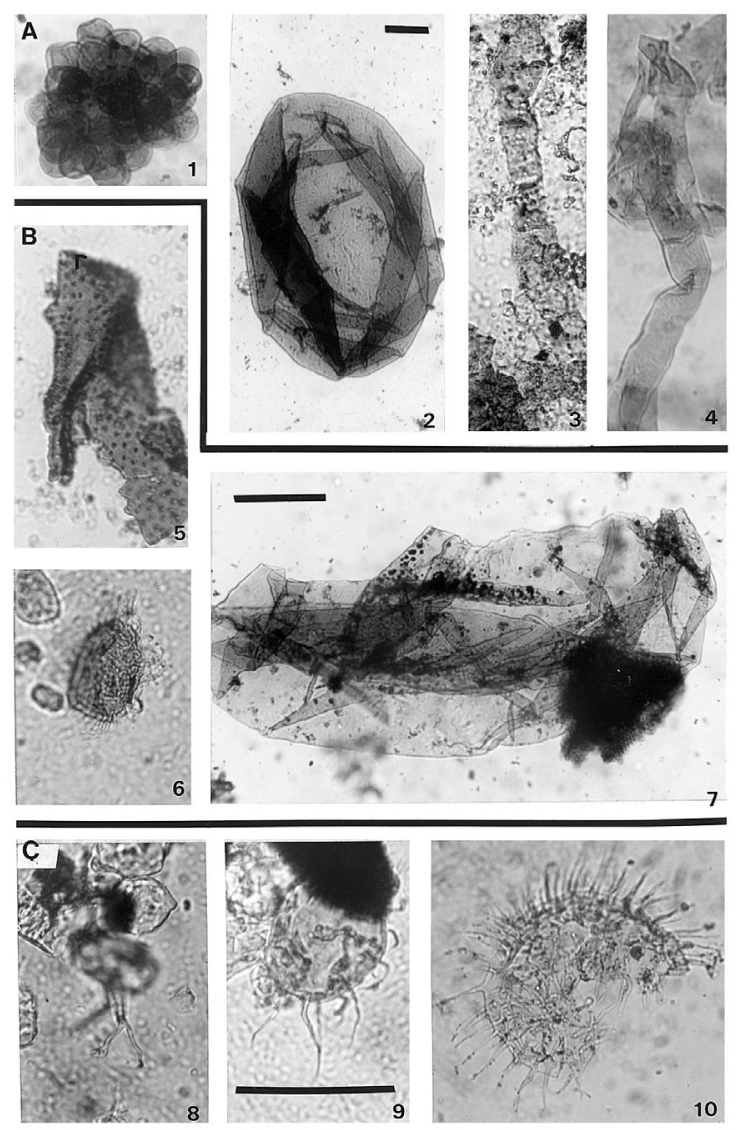

Plate I. Selected acritarchs in the Karikkoselkä impact crater. Proterozoic species: A1 Synsphaeridium sp., A2. Chuaria circularis, $A 3$. Oscillatoriopsis $c f$. constricta, $A 4$. Siphonophycus kestron. Cambrian species: B5. Tasmanites volkovae, $B 6$. Filisphaeridium molliculum, $B 7$. Tasmanites tenellus. Ordovician species: $C 8$. Diexallophasis striatum, C9. Baltisphaeridium hirsutoides, C10. Baltisphaeridium annelieae. Bars equal $50 \mu m$. Bar in Figure C9 is the same as in Figures A1, A3, A4, B5, $B 6, C 8$ and $C 10$.

agia compressa (Volkova, 1968) Downie, 1982 is found at a depth of $60.20 \mathrm{~m}$ in DC1. Two specimens of Filisphaeridium molliculum (Moczydlowska \& Vidal, 1988) Sarjeant \& Stancliffe, 1994 are found in DC1 at a depth of $73.65 \mathrm{~m}$ (Plate I, Fig. B6).

The living range of $F$. molliculum and T.tenellus is restricted to early Cambrian, while $F$. tornatum, Sk. compressa and T. volkovae are early to middle Cambrian species (Hagenfeldt 1989a, b, Moczydlowska 1991, and references herein). In the present material, none of the recorded species is restricted to middle Cambrian alone.

Ordovician acritarchs are very rare in the assemblage (less than $1 \%$ of the total specimens) and most of them are mechanically broken. Three thick-walled bright yellow cell fragments of genus Leiosphaeridia are similar to those recorded in Ordovician Rapla material (Uutela \& Tynni 1991). These Leiosphaeridia fragments are recorded at a depth of $34.15 \mathrm{~m}$ in DC1 and at depths of $73.25 \mathrm{~m}$ and $90.90 \mathrm{~m}$ in DC2.

Two whole specimens and two fragments of Baltisphaeridium hirsutoides Eisenack, (1931) 1958 are found in DC1 at depths of $34.05 \mathrm{~m}, 73.65$ $\mathrm{m}$ and $85.65 \mathrm{~m}$, and in DC2 at a depth of 106.50 m (Plate I, Fig. C9). Other Baltisphaeridium species in the assemblage are B. microspinosum (Eisenack, 1954) Downie, 1959 at a depth of 46.00 $\mathrm{m}$, B. parvigranosum Loeblich \& Tappan, 1978 at a depth of $51.30 \mathrm{~m}$ and B. annelieae Kjellström, 1976 emended Bockelie \& Kjellström, 1979 at a depth of $130.85 \mathrm{~m}$ in DC1 (Plate I, Fig. C10).

$B$. hirsutoides and B. microspinosum are typical Ordovician and early Silurian species in the Baltic area (Uutela \& Tynni 1991, and references herein). B. parvigranosum is recorded in middle Ordovician deposits in Estonia (Uutela \& Tynni 1991), in Sweden (Górka 1987) and in the U.S.A. (Loeblich \& Tappan 1978), but also in late Ordovician deposits in Estonia (Uutela \& Tynni 1991). In Estonia B. annelieae has been recorded previously from middle (Kunda Regional Stage in Estonian stratigraphy) to late Ordovician (Kukruse Regional Stage) deposits (Uutela \& Tynni 1991), and in Sweden and central Europe in middle Ordovician (Kjellström 1976, Bockelie \& Kjellström 1979, Górka 1979, 1987, Tynni 1982a, Turner 1984) as well as in late Ordovician deposits in the U.S.A. (Jacobson 1978). Half of Diexallophasis striatum (Uutela \& Tynni, 1991) Sarjeant \& Stancliffe, 1994 in DC1 is found at a depth of 34.05 $\mathrm{m}$ and the other half at a depth of $113.05 \mathrm{~m}$ (Plate I, Fig. C8). Previously it has been recorded only in the late Ordovician Keila Regional Stage at Rapla, Estonia (Uutela \& Tynni 1991), being extremely rare there.

In DC2 the uppermost sample of till (depth $13.80 \mathrm{~m}$ ) yields well preserved Quaternary pollen 
of Pinus, Picea, Alnus and Betula, which dominates, and spores of Lycopodium and Sphagnum.

\section{DISCUSSION}

Based on the acritarch results, the age of the Karikkoselkä impact event is impossible to estimate. The significant feature of the sedimentary deposit is the mixture of acritarch assemblages throughout the deposit reaching almost to the lowermost samples. The presence of Diexallophasis striatum gives the impact event its maximum age, i.e. it took place during the Keila Regional Stage (middle Caradocian in British Series, late Ordovician 458-449 Ma) or later. Quaternary pollen without acritarchs in the uppermost till sample indicates that, at the minimum, the impact event occurred prior to the Fennoscandian Ice Age, i.e. till was formed after the impact event.

Palaeomagnetic data gives three different ages for the impact of which the oldest, late Palaeoproterozoic (1760-1650 Ma) is according to Pesonen et al. (1999) less likely. Early Palaeozoic acritarchs in the deposits filling the crater would also rule out this age. The second age interpretation, i.e. late Neoproterozoic to early Cambrian (560 $530 \mathrm{Ma}$ ), is not supported by the present material because of the presence of Ordovician acritarchs. The palaeomagnetic data suggesting an age of 260-230 Ma (late Permian to early Triassic) is neither excluded nor supported by the microfossil results, but this is the most consistent. Northern Scandinavia was situated at $45^{\circ}$ on the northern hemisphere and was dry desert during the Permian (Lottes \& Rowley 1990, Nie et al. 1990). The nearest location with Triassic (Rhaetian, upper Triassic) microfossils is in Scania, southern Sweden (cf. Guy-Olsson 1981), but the assemblage is completely different from the present material. If the land area was covered with some kind of vegetation, no pollen or spores are preserved. If the Karikkoselkä area was covered with seawater or fresh waters, no acritarchs or green algae are preserved.

Based on the acritarch results, the pre-impact Karikkoselkä area was covered with Meso- and/ or Neoproterozoic deposits overlain by early Palaeozoic (early and/or middle Cambrian and early to late Ordovician) deposits. Sedimentary deposits in the crater consist of mudstone and siltstone, which are typical of Proterozoic and Cambrian sedimentary deposits in the Baltic area. Ordovician deposits consist of marl and limestone.

The acritarch results suggest that the Baltic Sea covered the Karikkoselkä area during Neoproterozoic and the early Cambrian. Absolute evidence of Mesoproterozoic deposits is lacking. Although none of the species in the present material have a living range restricted only to the middle Cambrian, it is likely that the sea also covered the Karikkoselkä area at the beginning of the middle Cambrian. This point of view is supported by the early middle Cambrian (Kibartai Regional Stage) acritarchs found at Söderfjärden (Hagenfeldt 1989b) and Lappajärvi, in western Finland (Uutela 1998). During the late middle Cambrian both Söderfjärden and Lappajärvi seem to have been dry land, obviously also the Karikkoselkä area.

Early Palaeozoic sea covered central Finland during the middle Ordovician, using terminology for Estonian regional stages, from Lasnamägi Regional Stage, when B. parvigranosum appeared, to the late Ordovician Kukruse Regional Stage, when B. annelieae disappeared. Absolute evidence of early Ordovician deposits is lacking. Because both $B$. hirsutoides and $B$. microspinosum have a living range from early Ordovician to early Silurian, an early Ordovician age is neither excluded nor supported. Lindström (1979) estimated an early Ordovician transgression to have covered central and eastern Finland, while Thorslund (1960) estimated it to have covered the whole of Scandinavia with the exception of the northeastern part of Finland. Röömusoks (1960), Jaanusson (1963) and Männil (1966) proposed narrower boundaries for the transgression. Hiatus and/or hiati are possible in the succession. It is possible that there is a hiatus between the late Ordovician Kukruse to Keila regional stages, i.e. in the Haljala Regional Stage (see Männil 1966). So far, Diexallophasis striatum is recorded only at the end of Keila Regional Stage, late Ordovician (Uutela \& Tynni 1991). 
Table 1. Occurrence and distribution of acritarch specimens in DC1. Legend: $A=$ Chuaria circularis, $B=$ Trachysphaeridium laminaritum, $C=$ Oscillatoriopsis $s p$., $D=$ Siphonophycus kestron, $E=\mathrm{S}$. rugosum, $F=$ Synsphaeridium spp., $G=$ Symplassosphaeridium $s p ., H=$ Granomarginata $s p ., I=$ Filisphaeridium tornatum, $J=$ Tasmanites volkovae, $K=\mathrm{T}$. tenellus, $L=$ Skiagia compressa, $M=$ Filisphaeridium molliculum, $N=$ Baltisphaeridium annelieae, $O=\mathrm{B}$. hirsutoides, $P=\mathrm{B}$. microspinosum, $Q=\mathrm{B}$. parvigranosum, $R=$ Diexallophasis striatum, $S=$ Leiosphaeridia $s p$.

\begin{tabular}{|c|c|c|c|c|c|c|c|c|c|c|c|c|c|c|c|c|c|c|c|c|c|c|c|c|c|c|c|c|c|c|}
\hline \multirow{3}{*}{$\frac{\text { Depth }}{\mathrm{m}}$} & \multicolumn{10}{|c|}{ Proterozoic - Tertiary } & \multicolumn{5}{|c|}{ Neoproterozoic } & \multicolumn{3}{|c|}{$\begin{array}{l}\text { Mesoprot. } \\
\text { Cambrian }\end{array}$} & \multicolumn{5}{|c|}{ Cambrian } & \multicolumn{6}{|c|}{ Ordovician } & \\
\hline & Leios & phaes & idia $\mathrm{s}$ & pp. $\varnothing$ & $\mu \mathrm{m}$ & & & & & $\sum$ & A & B & $\mathrm{C}$ & D & $\mathrm{E}$ & $\mathrm{F}$ & G & $\mathrm{H}$ & I & $\mathrm{J}$ & $\mathrm{K}$ & $\mathrm{L}$ & M & $\mathrm{N}$ & 0 & $\mathrm{P}$ & Q & $\mathrm{R}$ & $S$ & $\sum$ \\
\hline & $<10$ & $11-$ & 21- & $41-$ & 61- & \begin{tabular}{|l|}
101 \\
\end{tabular} & 151 & 200 & $>200$ & & & & & & & & & & & & & & & & & & & & & \\
\hline 34.05 & & & 2 & & & & 1 & & & 3 & & & & & & & & & & & & & & & 1 & & & 1 & & 5 \\
\hline 34.15 & & & 2 & 1 & & & & & & 3 & & & & & & & & & & & & & & & & & & & 1 & 4 \\
\hline 37.25 & & & & & & & & & & 0 & & & & & & 1 & & & 8 & 14 & & & & & & & & & & 23 \\
\hline 46.00 & 30 & & 10 & 20 & 4 & 8 & 4 & & & 76 & & 1 & & & & & & 1 & & & & & & & & 1 & & & & 79 \\
\hline 46.80 & & 4 & 2 & 8 & 6 & 30 & 32 & 5 & & 86 & & 1 & & & & 75 & 1 & 1 & 15 & & 1 & & & & & & & & & 181 \\
\hline 51.30 & 8 & 11 & 9 & 9 & 12 & 35 & 40 & 4 & 2 & \begin{tabular}{|l|}
130 \\
\end{tabular} & & 1 & & & & 8 & & 1 & 13 & & 7 & & & & & & 1 & & & 161 \\
\hline 55.25 & 2 & 2 & & & 1 & & & & & 5 & & & & & & 3 & & & & & & & & & & & & & & 8 \\
\hline 58.65 & 2 & 2 & 4 & 9 & 3 & 1 & 4 & & & 25 & & & & & & 3 & & & & & & & & & & & & & & 28 \\
\hline 59.60 & & 2 & 1 & 2 & 9 & 3 & 6 & 5 & & 27 & & & & & & 1 & & & 5 & 3 & 1 & & & & & & & & & 38 \\
\hline 60.20 & & & & & & 3 & 8 & 25 & 22 & 58 & & & & & & & & 1 & & & & 1 & & & & & & & & 60 \\
\hline 62.30 & & 4 & 3 & 3 & 1 & & & & & 11 & & & & & & & & & & 4 & & & & & & & & & & 15 \\
\hline 66.50 & 3 & & & 4 & 2 & 6 & 17 & & 5 & 37 & 4 & & & & & + & & & & 1 & & & & & & & & & & 42 \\
\hline 68.45 & 6 & 5 & 8 & 3 & & & & & & 22 & & & & & & & & 3 & & & 1 & & & & & & & & & 26 \\
\hline 68.65 & 20 & 20 & 6 & 4 & & 1 & & & & 51 & & & & & & & & 1 & & 3 & & & & & & & & & & 55 \\
\hline 73.65 & 4 & 3 & 7 & 14 & 12 & 4 & 2 & & & 46 & & & & & + & & & & & 8 & & & 2 & 1 & & & & & & 57 \\
\hline 74.70 & 1 & 1 & & 2 & & & & & & 4 & & 1 & & & & 1 & & & & & 2 & & & & & & & & & 8 \\
\hline 80.00 & & & 1 & & 1 & & & & & 2 & & & & & & & & & 3 & & & & & & & & & & & 5 \\
\hline 80.55 & & & 1 & 3 & 1 & & & & & 5 & + & & & & & & & 1 & 20 & 3 & & & & & & & & & & 29 \\
\hline 82.25 & & 2 & 1 & 3 & & & 1 & 2 & & 9 & & & & & & & & & & 1 & & & & & & & & & & 10 \\
\hline 84.00 & 1 & 6 & 8 & 6 & 2 & 1 & & & & 24 & & & & & & 3 & 1 & & 2 & & & & & & & & & & & 30 \\
\hline 85.65 & & & & & & & & & & 0 & & & & & & & & & & & & & & & 1 & & & & & 1 \\
\hline 91.55 & & & & & & & & & & 0 & & & & & & & & & & & & & & & & & & & & 0 \\
\hline 94.70 & 3 & 3 & 4 & 3 & 1 & & & & & 14 & & & & & & & & & 4 & & & & & & & & & & & 18 \\
\hline 95.15 & & & & & & & & & & 0 & & & & & & & & & & & & & & & & & & & & 0 \\
\hline 96.40 & & & 31 & 23 & 1 & 1 & 1 & & & 57 & & & + & & + & & & & & & & & & & & & & & & 57 \\
\hline 96.80 & 4 & 2 & 2 & 2 & & & & & & 10 & & & & & & & & & & & & & & & & & & & & 10 \\
\hline 98.75 & & & & & & & & & & 0 & & & & & & & & & & 1 & & & & & & & & & & 1 \\
\hline 103.05 & & & & & & & & & & 0 & & & & & & & & & & & & & & & & & & & & 0 \\
\hline 113.05 & & 7 & 19 & 24 & 10 & & & & & 60 & & & & + & + & & & & & & & & & & & & & + & & 60 \\
\hline 114.10 & & & 3 & 1 & & & & & & 4 & & & & & & & & & & & & & & & & & & & & 4 \\
\hline 114.80 & & & 25 & 24 & 4 & & 1 & & & 54 & & & & + & + & & & & & & & & & & & & & & & 54 \\
\hline 115.05 & 3 & 14 & 31 & 11 & 2 & & & & & 61 & & & & & + & & & & & & & & & & & & & & & 61 \\
\hline 116.40 & & 6 & 26 & 8 & 1 & & & & & 41 & & & & & + & & & & & & & & & & & & & & & 41 \\
\hline 116.80 & & 4 & 9 & 10 & 1 & & & & & 24 & & & & & & & & & & & & & & & & & & & & 24 \\
\hline 117.40 & & & 7 & 2 & & & & & & 9 & & & & + & + & & & & & & & & & & & & & & & 9 \\
\hline 118.40 & 1 & 34 & 30 & 8 & & & & & & 73 & & & & & + & & & & & & & & & & & & & & & 73 \\
\hline 119.45 & 1 & 2 & 24 & 11 & 1 & & & & & 39 & & & & & + & & & & & & & & & & & & & & & 39 \\
\hline 120.45 & 22 & 77 & 31 & 4 & 1 & & & & & 135 & & & & + & + & & & & & & & & & & & & & & & 135 \\
\hline 121.10 & 0 & 0 & 7 & 2 & 0 & 1 & & 1 & & \begin{tabular}{|l|}
11 \\
\end{tabular} & & & & & + & & & & & & & & & & & & & & & 11 \\
\hline 121.55 & & 2 & 22 & 8 & 3 & 1 & & & & 36 & & & & + & + & & & & & & & & & & & & & & & 36 \\
\hline 122.50 & 22 & 55 & 12 & 1 & & 1 & & & & 91 & & & & & + & & & & & & & & & & & & & & & 91 \\
\hline 124.00 & & & 2 & 9 & 5 & 4 & 2 & & 1 & 23 & & & & & & & & & & 13 & & & & & & & & & & 36 \\
\hline 125.60 & & 2 & & & & & & & & 2 & & & & + & + & & & & & & & & & & & & & & & 2 \\
\hline 126.70 & & & & & & & & & & 0 & & & & & & & & & & & & & & & & & & & & 0 \\
\hline 128.55 & 6 & 3 & 8 & 2 & 2 & & & & 2 & 23 & & & & & & & & & & & & & & & & & & & & 23 \\
\hline 130.85 & 4 & 9 & 6 & 11 & 8 & 4 & 9 & & & 51 & & & & & + & 15 & & & 16 & 5 & & & & 1 & & & & & & 88 \\
\hline 133.40 & & & & & & & & & & 0 & & & & & & & & & & & & & & & & & & & & 0 \\
\hline 138.45 & & & & & & & & & & 0 & & & & & & & & & & & & & & & & & & & & 0 \\
\hline 144.70 & 10 & 10 & 14 & & 1 & & 2 & & & 37 & & & & & & 11 & & 47 & 48 & & & & & & & & & & & 143 \\
\hline 151.95 & & & & & & & & & & 0 & & & & & & & & & & & & & & & & & & & & 0 \\
\hline 167.35 & 1 & 6 & 12 & 16 & 4 & 1 & & & & 40 & & & & & & & & & & & & & & & & & & & & 40 \\
\hline$\sum$ & 132 & 265 & 433 & 282 & 100 & 104 & 131 & 42 & 32 & 1519 & 4 & 4 & + & + & + & 121 & 2 & 56 & 134 & \begin{tabular}{|l|l|}
4 & 56 \\
\end{tabular} & 12 & 1 & 2 & 2 & 2 & 1 & 1 & 1 & 1 & 1920 \\
\hline
\end{tabular}


Table 2. Occurrence and distribution of acritarch specimens in DC2. Legend: Neopr. $=$ Neoproterozoic. $A=$ Siphonophycus kestron, $B=\mathrm{S}$. rugosum, $C=$ Filisphaeridium tornatum, $D=$ Tasmanites volkovae, $E$ $=$ Baltisphaeridium hirsutoides, $F=$ Leiosphaeridia $s p$.

\begin{tabular}{|c|c|c|c|c|c|c|c|c|c|c|c|c|c|c|c|c|c|}
\hline \multirow{3}{*}{$\begin{array}{l}\text { Depth } \\
\mathrm{m}\end{array}$} & \multirow{2}{*}{\multicolumn{10}{|c|}{$\begin{array}{l}\text { Proterozoic - Tertiary } \\
\text { Leiosphaeridia } \operatorname{spp} \varnothing \mu \mathrm{m}\end{array}$}} & \multicolumn{2}{|c|}{ Neopr } & \multicolumn{2}{|c|}{ Cambrian } & \multicolumn{2}{|c|}{ Ordovician } & \multirow[b]{3}{*}{$\sum$} \\
\hline & & & & & & & & & & & $\mathrm{A}$ & $\mathrm{B}$ & $\mathrm{C}$ & $\mathrm{D}$ & $\mathrm{E}$ & $\mathrm{F}$ & \\
\hline & $<10$ & $11-$ & 21- & $41-$ & $61-$ & 81- & $101-$ & $151-$ & $>200$ & $\sum$ & & & & & & & \\
\hline 13.80 & & & & & & & & & & 0 & & & & & & & 0 \\
\hline 29.90 & & & 3 & 5 & & & & & & 8 & & + & & & & & 8 \\
\hline 33.60 & 1 & 20 & 61 & 30 & 4 & 3 & 3 & & & 122 & + & & & & & & 122 \\
\hline 38.75 & & 4 & 60 & 18 & & & & & & 82 & & + & & & & & 82 \\
\hline 39.70 & 1 & 2 & 2 & 10 & & & & & & 15 & & & & & & & 15 \\
\hline 43.60 & & & 5 & 1 & & & & & & 6 & & & & & & & 6 \\
\hline 44.75 & & & & & & & & & & 0 & & & & & & & 0 \\
\hline 49.60 & & 1 & 1 & 1 & & & & & & 3 & & & & & & & 3 \\
\hline 53.70 & & 2 & 6 & 6 & & & & & & 14 & + & & & & & & 14 \\
\hline 55.00 & 11 & 28 & 20 & 15 & 2 & & & & & 76 & & & & & & & 76 \\
\hline 57.50 & & & & & & & & & & 0 & & & & & & & 0 \\
\hline 60.00 & & & & & & & & & & 0 & & & & & & & 0 \\
\hline 63.45 & & & 4 & 4 & 1 & & & & & 9 & & & & & & & 9 \\
\hline 65.85 & 1 & 6 & 6 & 2 & & & & & & 15 & & & & & & & 15 \\
\hline 67.10 & & & 2 & 3 & & & & & & 5 & & & & & & & 5 \\
\hline 73.25 & 1 & 9 & 2 & 1 & & & & & & 13 & & & & & & 1 & 14 \\
\hline 78.90 & 5 & 9 & & & & & & & & 14 & & & & & & & 14 \\
\hline 86.10 & & & & & & & & & & 0 & & & & & & & 0 \\
\hline 90.90 & & & & & & & & & & 0 & & & & & & 1 & 1 \\
\hline 96.60 & & 1 & & & & & & & & 1 & & & & & & & 1 \\
\hline 100.70 & & & & & & & & & & 0 & & & & & & & 0 \\
\hline 106.50 & & & & & & & & & & 0 & & & & & 1 & & 1 \\
\hline 112.70 & & & & 4 & 3 & 17 & 33 & 1 & 4 & 63 & & & 1 & 2 & & & 66 \\
\hline 120.35 & & & & & & & & & & 0 & & & & & & & 0 \\
\hline 123.40 & 1 & 4 & 6 & 2 & 1 & & & & & 14 & & & & & & & 14 \\
\hline 129.20 & & & & & & & & & & 0 & & & & & & & 0 \\
\hline 130.70 & & & & & & & & & & 0 & & & & & & & 0 \\
\hline$\sum$ & 21 & 86 & 178 & 102 & 11 & 20 & 36 & 1 & 4 & 460 & + & + & 1 & 2 & 1 & 2 & 466 \\
\hline
\end{tabular}

\section{CONCLUSIONS}

1. Brecciated and redeposited sedimentary rocks of the Karikkoselkä impact crater yield a mixed assemblage with Proterozoic and early Palaeozoic (Cambrian and Ordovician) cyanobacteria, green algae and acritarchs.

2. The microfossil results of this study neither support nor exclude the most likely age of the impact event (260-230 Ma, late Permian to early Triassic). The results contradict two other possible palaeomagnetic datings, i.e. late $\mathrm{Ne}-$ oproterozoic to early Cambrian (560-530 Ma) and Proterozoic (1760-1650 Ma).

3. The microfossil assemblage gives new information on pre-impact sedimentary rocks covering central Finland.

ACKNOWLEDGEMENTS. I would like to thank Drs Lauri Pesonen and Martti Lehtinen for offering this interesting material to study, Anja Arkonsuo (M.Sc.) for the lithological description of drill 
cores, professor Tadas Jankauskas and Dr. Stewart Molyneaux for critical reading and Nancy Seidel for checking the English language. Their help is warmly appreciated.

\section{REFERENCES}

Abels, A., Bergman, L., Lehtinen, M. \& Pesonen, L. 2000. Structural constraints and interpretations on the formation of the Söderfjärden and Lumparn impact structures, Finland. In: Plado, J. \& Pesonen, L. (eds.) Meteorite Impacts in Precambrian Shields. Programme and Abstracts, the $4^{\text {th }}$ Workshop of the European Science Foundation Impact Programme, Lappajärvi - Karikkoselkä - Sääksjärvi, Finland May 24-28. 2000. Geological Survey of Finland and University of Helsinki. p. 26.

Arkonsuo, A. 2000. Impaktimetamorfoosi ja Karikkoselän kraatteri Petäjävedellä. Unpublished master's thesis, University of Helsinki, Department of Geology. 123 p. (in Finnish)

Bockelie, T.G. \& Kjellström, G. 1979. Middle Ordovician acritarchs from the island of Odinsholm, Estonia. Geologiska Föreningens i Stockholm Förhandlingar 101, 205-216.

Chibrikova, E.V. 1972. Rastitelnye mikrofossilii yuzhnogo Urala i Priurala (Iz siluriyskikh i devonskikh otlozhenyi). Akademiya Nauk USSR, Bashkirskii Filial, Institu Geologii. 220 p. (in Russian)

Elo, S., Kuivasaari, T., Lehtinen, M., Sarapää, O. \& Uutela, A. 1993. Iso-Naakkima, a circular structure filled with Neoproterozoic sediments, Pieksämäki, southeastern Finland. Bulletin of the Geological Society of Finland 65, 3-30.

Górka, H. 1979. Les Acritarches de l'Ordovicien moyen d'Olsztyn IG 2 (Pologne). Acta Paleontologica Polonica 24, 351-376.

Górka, H. 1987. Acritarches et Prasinophyceae de 1'Ordovicien moyen (Viru) du sondage de Smedsby Gård No 1 (Gotland, Suède). Review of Paleobotany and Palynology 52, 257-297.

Guy-Olsson, D. 1981. Rhaeto-Liassic palynostratigraphy of the Valhall bore No. 1, Scania. Geologiska Föreningens i Stockholm Förhandlingar 103, 233-248.

Hagenfeldt, S. 1989a. Lower Cambrian acritarchs from the Baltic Depression and southcentral Sweden, taxonomy and biostratigraphy. Stockholm Contributions in Geology 41, 1-176.

Hagenfeldt, S. 1989b. Middle Cambrian acritarchs from the Baltic Depression and southcentral Sweden, taxonomy and biostratigraphy. Stockholm Contributions in Geology 41, 177-250.

Hansen, W.R. 1991. Suggestion to Authors of the reports of the United States Geological Survey, $7^{\text {th }}$ edition. Washington, D.C., U.S. Government Printing Office. $289 \mathrm{p}$.

Hofmann, H.J. \& Jackson, G.D. 1994. Shale-facies micro- fossils from the Proterozoic Bylot Supergroup, Baffin Island, Canada. The Palaeontological Society Memoir $37.39 \mathrm{p}$.

Jaanusson, V. 1963. Classification of the Harjuan (Upper Ordovician) rocks of the mainland of Sweden. Geologiska Föreningens i Stockholm Förhandlingar 85, 110144.

Jacobson, S.R. 1978. Acritarchs from the Upper Ordovician Clays Ferry Formation, Kentucky, U.S.A. Palinologia número Extraordinario 1, 293-310.

Jessberg, E.K. \& Reimold, W.U. 1980. A Late Cretaceous ${ }^{40} \mathrm{Ar}-{ }^{39} \mathrm{Ar}$ age for the Lappajärvi Impact Crater, Finland. Journal of Geophysics 48, 57-59.

Kjellström, G. 1976. Lower Viruan (Middle Ordovician) microplancton from the Ekön Borehole No 1. in Östergötland, Sweden. Sveriges Geologiska Undersökning, Serie C 724, Årsbok 70. 44 p.

Laurén, L., Lehtovaara, J. \& Boström, R. 1978. On the geology of the circular depression at Söderfjärden, western Finland. Geological Survey of Finland, Bulletin 297, $5-38$.

Lehtinen, M. 1976. Lake Lappajärvi, a meteorite impact site in western Finland. Geological Survey of Finland, Bulletin 282. 92 p.

Lehtinen, M. Pesonen, L.J. Puranen, R. \& Deutsch, A. 1996. Karikkoselkä - a new impact structure in Finland. In: $27^{\text {th }}$ Lunar and Planetary Science Conference, Abstracts. Houston: Lunar and Planetary Institute, 739-740.

Lehtovaara, J.J. 1984. Vaasan Söderfjärden - sedimenttiaineksen suojaama kambrikaudella muodostunut kraatteri. Summary: Söderfjärden, Vaasa, western Finland: a crater covered with sedimentary material since its formation in the Cambrian. Terra 96, 23-33.

Lehtovaara, J. 1985. ${ }^{40} \mathrm{~K}-{ }^{40} \mathrm{Ar}$ dating of the Söderfjärden crater, Vaasa, western Finland. Geologiska Föreningens i Stockholm Förhandlingar 107, 1-6.

Lindström, M. 1979. Diagenesis of Lower Ordovician hardgrounds in Sweden. Geologica et Palaeontologica 13, 9-30.

Lottes, A.L. \& Rowley, D.B. 1990. Early and Late Permian reconstructions of Pangaea. In: McKerrow, W.S. \& Scotese, C.R. (eds.) Palaeozoic Palaeogeography and Biogeography. Geological Society of London, Memoir 12, 383-395.

Loeblich, A.R. Jr. \& Tappan, H. 1978. Some Middle and Late Ordovician microphytoplancton from central North America. Journal of Paleontology 52:6, 1233-1287.

Lopukin, A.S. 1974. Mikrofossilii rifeya severo-vostochnogo Prianabarya (nizove r Leny pos. Chekurovka). Isvestiya Vysshikn Uchebnikh Xavedenii, Geologiya i Razvedka 7, 37-44. (in Russian)

Männil, R. 1966. Evolution of the Baltic basin during Ordovician. Tallinn Eesti NSV Teaduste Akadeemia Geoloogia Instituut. 199 p. (in Russian with English summary)

Moczydlowska, M. 1991. Acritarch biostratigraphy of the Lower Cambrian and the Precambrian - Cambrian boundary in southeastern Poland. Fossils and Strata 29. 97 p.

Nie, S., Rowley, D.B. \& Ziegler, A.M. 1990. Constraints 
on the location of the Asian microcontinents in PalaeoTethys during the Late Palaeozoic. In: McKerrow, W.S. \& Scotese, C.R. (eds.) Palaeozoic Palaeogeography and Biogeography. Geological Society of London, Memoir 12, 397-409.

Öhman, T., Pesonen, L.J., Raitala, J., Uutela, A. \& Tuisku, P. 2000. The Saarijärvi crater - older and larger than assumed? In: Plado, J. \& Pesonen, L. (eds.) Meteorite Impacts in Precambrian Shields. Programme and Abstracts, the $4^{\text {th }}$ Workshop of the European Science Foundation Impact Programme, Lappajärvi - Karikkoselkä - Sääksjärvi, Finland, May 24-28. 2000. Geological Survey of Finland and Department of Geophysics, University of Helsinki, p. 82.

Pesonen, L.J., Elo, S., Puranen, R., Jokinen, T., Lehtinen, M., Kivekäs, L. \& Suppala, I. 1997. The Karikkoselkä impact structure, central Finland: new geophysical and petrographic results. In: Conference on Large Meteorite Impacts and Planetary Evolution (Sudbury 97), LPI Contribution No. 922, Lunar and Planetary Institute, Houston, p. 39.

Pesonen, L.J., Elo, S., Puranen, R., Jokinen, T., Lehtinen, M., Kivekäs, L. \& Kouvo, O. 1998. The Karikkoselkä impact structure - integrated results and interpretation models. Open File Report Q29.1/98/3, Laboratory for Paleomagnetism, Geological Survey of Finland. 35 p.

Pesonen, L.J., Elo, S., Lehtinen, M., Jokinen, T., Puranen, R. \& Kivekäs, L. 1999. Lake Karikkoselkä impact structure, central Finland: New geophysical and petrographic results. In: Dressler, B.O. \& Sharpton, V.L. (eds.) Large Meteorite Impacts and Planetary Evolution II. Geological Society of America, Special Paper 339, 131-147.

Röömusoks, A. 1960. Stratigraphy and paleogeography of the Ordovician in Estonia. 21st International Geological Congress, Part VII, Proceedings of Session 7 Ordovician and Silurian stratigraphy and correlations, 58-69.

Samuelsson, J. 1997. Biostratigraphy and palaeobiology of Early Neoproterozoic strata of the Kola Peninsula, Northwest Russia. Norsk Geologisk Tidsskrift 77, 1-28.

Samuelsson, J. \& Strauss, H. 1999. Stable isotope geochemistry and palaeobiology of the upper Visingsö Group (early Neoproterozoic), southern Sweden. Geological Magazine 136, 63-73.

Sarjeant, W.A.S. \& Stancliffe, R.P.W. 1994. The Micrhystridium and Veryhachium complexes (Acritarcha: Acanthomorphitae and Polygonomorphitae): a taxonomic reconsideration. Micropaleontology 40, 1-77.

Svensson, N.-B. 1968. Lake Lappajärvi, Central Finland: a possible meteorite impact structure. Nature 217, p. 438.

Svensson, N.-B. 1993. Lumparn Bay: a meteorite impact crater in the Aland Archipelago, southwest Finland. Meteoritics 28, p. 445.

Timofeev, B.V. 1966. Mikropaleofitologicheskoe issledovanie drevnih svit. Akad. Nauk. S.S.S.R., Moscou Leningrad. 147 p. (in Russian)
Thorslund, P. 1960. The Cambro-Silurian. In: Hesslund, I. (ed.) Description to accompany the map of the pre-Quaternary rocks of Sweden. Sveriges Geologiska Undersökning, Series Ba. 16, 96-110.

Topinka, Lyn 2001. The Geologic Time Scale. U.S. Geological Survey. http://vulcan.wr.usgs.gov/Glossary/ geo_time_scale.html.

Turner, R.E. 1984. Acritarchs from the type area of the Ordovician Caradoc Series, Shropshire, England. Palaeontographica B 190, 87-157.

Tynni, R. 1978. Lower Cambrian fossils and acritarchs in the sedimentary rocks of Söderfjärden, western Finland. Geological Survey of Finland, Bulletin 297, 39-81.

Tynni, R. 1982a. New results of studies on the fossils in the Lower Cambrian sediment deposit of Söderfjärden. Bulletin of the Geological Society of Finland 54, 5768.

Tynni, R. 1982b. On Paleozoic microfossils on clastic dykes in the Aland Islands and in the core samples of Lumparn. Geological Survey of Finland, Bulletin 317, 35-94.

Tynni, R. \& Donner, J. 1980. A microfossil and sedimentation study of the late Precambrian formation of Hailuoto, Finland. Geological Survey of Finland, Bulletin 311. $27 \mathrm{p}$.

Tynni, R. \& Uutela, A. 1984. Microfossils from the Precambrian Muhos formation in western Finland. Geological Survey of Finland, Bulletin 330. 38 p.

Tynni, R. \& Uutela, A. 1985. Myöhäisprekambrinen ajoitus Taivalkosken savikivelle mikrofossiilien perusteel1a. Summary: Late Precambrian shale formation of Taivalkoski in northern Finland. Geologi 37, 61-65.

Uutela, A. 1990. Proterozoic microfossils from the sedimentary rocks of the Lappajärvi impact crater. Bulletin of the Geological Society of Finland 62, 115-121.

Uutela, A. 1998. Extent of the northern Baltic Sea during the Early Palaeozoic Era - new evidence from Ostrobothnia, western Finland. Bulletin of the Geological Society of Finland 70, 51-68.

Uutela, A. \& Tynni, R. 1991. Ordovician acritarchs from the Rapla borehole, Estonia. Geological Survey of Finland, Bulletin 353. 135 p.

Vidal, G. 1988. A palaeontological preparation method. Palynology 12, 215-220.

Vidal, G. \& Ford, T.D. 1985. Microbiotas from the late Proterozoic Chuar Group (northern Arizona) and Uinta Mountain Group (Utah) and their chronostratigraphic implications. Precambrian Research 28, 349-389.

Vidal, G., Moczydlowska, M. \& Rudavskaya, V. 1993 Biostratigraphical implications of a Chuaria-Tawuia assemblage and associated acritarchs from the Neoproterozoic of Yakutia. Palaeontology 36, 387-402. 